\title{
Effects of pH and ionic strength on the protease activity of gastric extracts from the Coho salmon Oncorhynchus kisutch
}

\author{
Lorenzo Márquez ${ }^{1}$, Adrián J. Hernández ${ }^{1}$, Edison S.M. Carvalho ${ }^{2,3}$, Gabriel A. Morales ${ }^{4,5}$ \\ Patricio Dantagnan ${ }^{1}$, Manuel Díaz ${ }^{6} \&$ Francisco J. Moyano $^{6}$ \\ ${ }^{1}$ Núcleo de Investigación en Producción Alimentaria, Departamento de Ciencias Agropecuarias y Acuícolas \\ Facultad de Recursos Naturales, Universidad Católica de Temuco, Temuco, Chile \\ ${ }^{2}$ Instituto Gulbenkian de Ciência, Telomeres and Genome Stability Group, Oeiras, Portugal \\ ${ }^{3}$ Universidade de Cabo Verde, Praia-Santiago, Cabo Verde \\ ${ }^{4}$ Departamento de Producción Animal, Facultad de Agronomía, Universidad de Buenos Aires \\ Buenos Aires, Argentina \\ ${ }^{5}$ Instituto de Investigaciones en Producción Animal, Consejo Nacional de Investigaciones \\ Científicas y Técnicas, Buenos Aires, Argentina \\ ${ }^{6}$ Grupo de Nutrición y Alimentación Animal, Departamento de Biología y Geología \\ Universidad de Almería, Almería, España \\ Corresponding author: Lorenzo Márquez (marquez.lorenzo728@gmail.com)
}

\begin{abstract}
The activity of fish acid proteases is strongly dependent on the $\mathrm{pH}$, and many basic and applied works had focused on researching the $\mathrm{pH}$-profile of digestive proteases using different buffered media. Nevertheless, enzymatic activity is also known to be affected by the ionic strength (IS) of the medium. The present work is aimed at researching the combined effects of $\mathrm{pH}(2.5,3.0,3.5,3.75$ and 4.0) and IS (50, 100 and $200 \mathrm{mM}$ ) on the protease activity of gastric extracts of juvenile Coho salmon Oncorhynchus kisutch. It is concluded that the activity of Coho salmon gastric proteases is maximal at $\mathrm{pH} 2.5-3.0$, drops towards $\mathrm{pH} 4.0$ irrespective of ionic strength, and they showed a lower activity at IS $50 \mathrm{mM}$ in comparison to IS 100 or 200 $\mathrm{mM}$. The present results point out to the convenience of considering the effect of ionic strength when measuring the activity of fish gastric proteases.
\end{abstract}

Keywords: Oncorhynchus kisutch; Coho salmon, gastric proteases; enzymatic activity; pH, ionic strength

Many of the fish species with commercial interest possess a functional stomach from the end of the metamorphosis onwards. In vertebrates, the stomach controls the delivering of chyme into the duodenum and promotes the breakdown of polypeptides into oligopeptides (Grabner \& Hofer, 1989). In larval digestion, the action of pepsin determines an important increase in the assimilation of proteins in Hippoglossus hippoglossus (Tonheim et al., 2005) and a moderate improvement in the in vitro digestibility of fish muscle (Tonheim et al., 2007) and is considered one of the cues to introduce inert diets in feeding protocols for fish larvae (Rønnestad et al., 2013). The gastric digestion of proteins is based upon two secretory processes, the acidification of the gastric lumen and the secretion of zymogens, mainly acidic proteases, carried out by oxynticopeptic cells located in the glands of the stomach of fishes (Bomgren et al., 1998). The activity of gastric proteases depends on the degree of acidification attained in the lumen of the stomach, this is the reason why the activity of acidic proteases is measured in relation to gastric $\mathrm{pH}$ (Márquez et al., 2012). For example, when dealing with feeding protocols (Chiu \& Pan, 2002; Campoverde et al., 2017; Bravo et al., 2018), the inclusion of new protein sources (Sotoudeh et al., 2016) and the utilization of feed additives (Castillo et al., 2014) in larval or juvenile fish. In general, the proteolytic activity of gastric extracts from fish shows a maximum value in the $\mathrm{pH}$ range 2.0-3.0 and a subsequent steep drop before the $\mathrm{pH}$ reaches 4.0 (Munilla-Morán \& Rey-Saborido, 1996a; Alarcón et al., 1998; Chong et al., 2002; Xiong et al., 2011; Peña et al., 2015). Thus, the range of $\mathrm{pH}$ between 2.0 and 4.0 is particularly interesting to understand the proteolytic capacity of the stomach in fish. 
Nevertheless, in addition to the apparent effect of $\mathrm{pH}$, the enzymatic activity is also affected by the ionic strength, a factor not so frequently investigated about digestive enzymes of fish. It is known that the ionic strength (IS) determines the folding of proteins in solution (Gabrielczyk et al., 2017) and/or the protein/ ligand binding affinity (Papaneophytou et al., 2014), and there is no a priori reason to rule out these effects in the case of digestive enzymes of fish or any other animal taxon. Indeed, the addition of $\mathrm{NaCl}$ to the reaction buffer changes the amylolytic and proteolytic activities of gut extracts from marine fish, the size of the change being dependent on the kind of enzymatic activity and the fish species under research (MunillaMorán \& Rey-Saborido, 1996a,b). Data on the ionic environment in the gut of fish are scarce, although a value for gastric IS over $200 \mathrm{mM}$ can be inferred from the detailed work by Bucking \& Wood (2009) on the postprandial distribution of $\mathrm{Na}^{+}, \mathrm{K}^{+}, \mathrm{Ca}^{2+}, \mathrm{Mg}^{2+}$ and $\mathrm{Cl}^{-}$ along with the gut of juvenile rainbow trout. The present work is aimed at disclosing the combined effects of $\mathrm{pH}$ and ionic strength on the proteolytic activity of gastric extracts of the Coho salmon, Oncorhynchus kisutch, a cultivated species of commercial importance in Chilean aquaculture. According to SERNAPESCA (2019), the Chilean production of Coho salmon reached approx. 15 and $19 \%$ of the total biomass of salmonid species cultured in 2016 and 2017, respectively.

Juveniles of Coho salmon were stocked in $500 \mathrm{~L}$ tanks connected to a freshwater flow-through system at the facilities of Departamento de Ciencias Agropecuarias y Acuícolas of Universidad Católica de Temuco (Chile). Fish received a daily ration (1\% body weight) of a 53/17 protein/lipid diet. The tank was regularly cleaned from feces and uneaten feed. Sampling protocols always included anesthesia of fish with isoeugenol (Aqui-s; Bayer Animal Health, Santiago, Chile) prior of being euthanized according to Chilean legal requirements on experimental animals (Ministerio de Salud de Chile, Ley 20380). Crude gastric extracts were obtained from the stomachs of seven fish weighing $92 \pm 11 \mathrm{~g}$ after dissection and homogenization of the tissue in $0^{\circ} \mathrm{C}$ distilled water $(1: 3 \mathrm{w} / \mathrm{v})$. Extracts were centrifuged at $15,800 \mathrm{~g}$ for $15 \mathrm{~min}$ at $4^{\circ} \mathrm{C}$, and the supernatant stored in aliquots at $-20^{\circ} \mathrm{C}$ until used in assays of acid protease activity by the method of Anson (1938). The substrate used was bovine hemoglobin $0.5 \% \mathrm{w} / \mathrm{v}$ in citric buffer $30 \mathrm{mM}$. The buffer was prepared at $\mathrm{pH}$ values $2.50,3.00,3.50,3.75$ and 4.00 and the ionic strength (IS) to 50, 100 and 200 $\mathrm{mM}$ (with $\mathrm{NaCl}$ ), thus resulting in a $5 \times 3$ factorial experiment. The experimental range of $\mathrm{pH}$ was selected according to i) the recorded values of postprandial gut
pH in salmonids (Bucking \& Wood, 2009; Bravo et al., 2018) and, ii) the general pattern of activity of fish gastric proteases in relation to $\mathrm{pH}$, with a maximum at 2.0-3.0 and a subsequent substantial drop before $\mathrm{pH}$ reaches 4.0. The range of ionic strength was selected by considering the postprandial ionic composition of the gastric chyme in salmonids (Bucking \& Wood, 2009), implying an ionic strength over $200 \mathrm{mM}$, and also the reaction buffers used to test acid proteases in vitro which often, contrary to the fluid phase of the gastric chyme, do not contain additional ions affecting ionic strength. Bovine hemoglobin was chosen as the suitable protease substrate since it is frequently utilized in works dealing with fish gastric proteases. Extracts were diluted in distilled water 1:8 v/v before the assay, which was carried out for $15 \mathrm{~min}$ at $25^{\circ} \mathrm{C}$. The reaction was stopped with $0.5 \mathrm{~mL}$ of $20 \% \mathrm{w} / \mathrm{v}$ trichloroacetic acid and centrifuged at $15,800 \mathrm{~g}$ for $15 \mathrm{~min}$ at $20^{\circ} \mathrm{C}$. The supernatant was collected and the absorbance at $280 \mathrm{~nm}$ was measured (Perkin-Elmer Lambda 25 UV/Vis Spectrophotometer). Two experimental assays and one blank assay were performed for each combination of factor levels and each fish, resulting in more than 300 spectrophotometric measurements. The activity was estimated from the difference in absorbance between the experimental assays and the blank, and setting the extinction coefficient of L-tyrosine at $0.008 \mathrm{~mL}(\mu \mathrm{g}$ $\mathrm{cm})^{-1}$. The protease activity was expressed as $\mu \mathrm{g}$ L-Tyr released per min and $\mathrm{g}$ of gastric tissue. Data on protease activity were analyzed using a two-factor $(\mathrm{pH}$, IS) $5 \times 3$ repeated-measure ANOVA. Type I error was fixed at 0.05 .

Both factors, $\mathrm{pH}$ and the ionic strength of the buffer, exerted a significant effect on protease activity (Tables 1 and 2). The activity showed a maximal value in the $\mathrm{pH}$ range 2.5-3.0 and dropped as $\mathrm{pH}$ increased from 3.0 to $\mathrm{pH} 4.0$ for IS $50 \mathrm{mM}$ and $100 \mathrm{~mm}$, following a convex pattern for all the levels of ionic strength tested. In the case of IS $200 \mathrm{mM}$, protease activity showed a general decreasing pattern in the $\mathrm{pH}$ range 3.0-4.0, barring the $\mathrm{pH}$ sub-interval 3.50-3.75, for which the activity seemed to maintain its value close to 12,000 units. On the other hand, the activities obtained at 50 $\mathrm{mM}$ of IS were always lower than those for 100 and 200 $\mathrm{mM}$, respectively. The interaction term was significant, most probably indicating that values for IS $200 \mathrm{mM}$ tended to be below values for IS $100 \mathrm{mM}$ just in the $\mathrm{pH}$ interval 2.5-3.5, but the reverse pattern was apparent in the $\mathrm{pH}$ interval 3.5-4.0. It is useful to check the ratio (activity at $\mathrm{pH} 3.0$ )/(activity at $\mathrm{pH} 4.0$ ), to understand the relationship between the effects of $\mathrm{pH}$ and IS on the activity of gastric proteases, whose values were 2.34, 2.19 and 1.88 for IS values of 50, 100 and $200 \mathrm{mM}$, respectively. In addition, the complementary ratio (activi- 
Table 1. Acid protease activities of gastric extracts from juvenile Coho salmon (Oncorhynchus kisutch) concerning $\mathrm{pH}$ and ionic strength $(\mathrm{mM})$. Activities are expressed as mean values $(\mathrm{n}=7) \pm \mathrm{SEM}$ (standard error of the mean). The activity unit is defined as $1 \mu \mathrm{g}$ of tyrosine released per min and $g$ of gastric tissue.

\begin{tabular}{lccr}
\hline \multirow{2}{*}{$\mathrm{pH}$} & \multicolumn{3}{c}{ Ionic strength $(\mathrm{mM})$} \\
\cline { 2 - 4 } & 50 & 100 & 200 \\
\hline 2.50 & $12,539 \pm 1,071$ & $15,028 \pm 1,279$ & $14,351 \pm 917$ \\
3.00 & $12,382 \pm 897$ & $15,351 \pm 987$ & $15,010 \pm 742$ \\
3.50 & $10,714 \pm 757$ & $13,219 \pm 794$ & $11,686 \pm 968$ \\
3.75 & $8,312 \pm 596$ & $10,852 \pm 652$ & $12,090 \pm 841$ \\
4.00 & $5,281 \pm 308$ & $6,997 \pm 391$ & $7,989 \pm 416$ \\
\hline
\end{tabular}

vity at ionic strength $200 \mathrm{mM}) /($ activity at ionic strength $50 \mathrm{mM}$ ) was 1.21 and 1.51 for $\mathrm{pH}$ values 3.0 and 4.0, respectively.

The $\mathrm{pH}$-profile of gastric proteases of the Coho salmon resembles that reported for other fish species (Alarcón et al., 1998; Castillo-Yáñez et al., 2004; Xiong et al., 2011). The same basic pattern was obtained for IS ranging 50-200 $\mathrm{mM}$, although the activity at $50 \mathrm{mM}$ stood below those at 100 and 200 $\mathrm{mM}$. From the point of view of the gastric function, this result is in keeping with the known ionic conditions in the stomach lumen after the ingestion of commercial pellets by juvenile trout, where the IS due to the main ions is above $200 \mathrm{mM}$ (Bucking \& Wood, 2009). Nevertheless, the direction of the effect of IS is probably species-specific, since a decrease in the caseinolytic activity of gastric extracts from three species of marine fish was reported by Munilla-Morán \& Saborido-Rey (1996a) when the concentration of $\mathrm{NaCl}$ in the reaction medium $(100 \mathrm{mM} \mathrm{HCl}$-glycine buffer, $\mathrm{pH}$ 2.0) raised from 0 to $200 \mathrm{mM}$. Alternatively, it can be thought that the $\mathrm{pH}$-profile is dependent on the chosen protease substrate (which is usually bovine hemoglobin when following the Anson protocol (Anson, 1938)). The $\mathrm{pH}$-profile of fish gastric proteases in the $\mathrm{pH}$ range 3.0-4.0 is of particular interest because it usually implies a change from optimal to suboptimal activity. The interactive effect between $\mathrm{pH}$ and IS (Table 2) is probably related to the following result: the protease activity at ionic strength $100 \mathrm{mM}$ is above that one at ionic strength $200 \mathrm{mM}$ provided the $\mathrm{pH}$ is $\leq 3.50$, but the opposite is true when $\mathrm{pH}$ is $\geq 3.75$.

This result is in keeping with the potential effects of ionic strength on protein structure and protein-ligand binding affinity (Papaneophytou et al., 2014). The

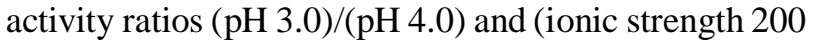
$\mathrm{mM}$ )/(ionic strength $50 \mathrm{mM}$ ) are beneficial to illustrate the way both factors combine to determine the activity
Table 2. Repeated-measures ANOVA on total acid protease activity ( $\mathrm{U} \mathrm{g}^{-1}$ stomach) from Coho salmon (Oncorhynchus kisutch) stomach homogenates by $\mathrm{pH}$ and ionic strength. Both factors are treated as repeated measures factors. IS: ionic strength in $\mathrm{mM}$; df: degrees of freedom; MS: mean squares; F: F-value; $P$ : $P$-value.

\begin{tabular}{lccccc}
\hline Source & df & MS & F & $P$ & $\begin{array}{c}\text { Homogeneous } \\
\text { groups }\end{array}$ \\
\hline IS & 2 & $6.8 \times 10^{7}$ & 37.8 & $<0.001$ & 50 vs 100,200 \\
$\mathrm{pH}$ & 4 & $2.0 \times 10^{8}$ & 97.4 & $<0.001$ & $\begin{array}{c}2.5,3.0 \text { vs } 3.5 \\
\text { vs } 3.75 \text { vs } 4.0\end{array}$ \\
& & & & & - \\
\hline
\end{tabular}

of gastric proteases. The revision of both ratios indicates that the further one of the factors is from its optimal range, the stronger is the effect of a change towards sub-optimal values in the other one. In this way, IS can soften the relative drop of activity associated with an increase in gastric $\mathrm{pH}$, as long as IS maintains around $200 \mathrm{mM}$. An interesting derived hypothesis is the potential effect of the mineral composition and solubility of the diet on the protease activity at the beginning of digestion, when the gastric $\mathrm{pH}$ is high, through the ionic environment of the gastric chyme. In species such as the rainbow trout Oncorhynchus mykiss, the period for which the gastric $\mathrm{pH}$ keeps at high values (4.0-5.0) extends for many hours after feed ingestion (Bucking \& Wood, 2009).

On the other hand, considering that in other fish species the ratio of acid protease activity $(\mathrm{pH} 3.0) /(\mathrm{pH}$ 4.0) can be higher than 5.0 (Alarcón et al., 1998), it can be concluded that this ratio may differ among fish families. Another line to be explored in the future is the consequences on the solubility of dietary proteins in the stomach of fish. Previous in vitro results indicate that the solubility of glycinin, one of the more abundant proteins in soybean depends strongly on both $\mathrm{pH}$ and IS (Lakemond et al., 2000), which is important for protein digestion because solubilized proteins can be more easily accessed by proteases.

In summary, the results are here presented to support the following facts in relation to the gastric proteases of the Coho salmon: i) an optimum $\mathrm{pH}$ in the range 2.5-3.0, ii) a significant effect of ionic strength (IS) on the activity of gastric proteases, with the lowest values when IS is below $100 \mathrm{mM}$, and iii) a mild interaction between the effects of $\mathrm{pH}$ and IS. Thus, we propose taking into account, not only the $\mathrm{pH}$ but also the ionic strength of the reaction medium when assaying the activity of fish gastric proteases.

This investigation was funded by the project MECESUP UCT 0804 obtained by Universidad Católica de Temuco (Chile). 


\section{REFERENCES}

Alarcón, F.J., Díaz, M., Moyano, F.J. \& Abellán, E. 1998. Characterization and functional properties of digestive proteases in two sparids; gilthead seabream (Sparus aurata) and common dentex (Dentex dentex). Fish Physiology and Biochemistry, 19: 257-267.

Anson, M.L. 1938. The estimation of pepsin, trypsin, papain, and cathepsin with hemoglobin. Journal of General Physiology, 22: 79-89.

Bomgren, P., Einarsson, S. \& Jönsson, A.C. 1998. Similarities and differences in oxynticopeptic cell ultrastructure of one marine teleost, Gadus morhua and one freshwater teleost, Oncorhynchus mykiss, during basal and histamine-stimulated phases of acid secretion. Fish Physiology and Biochemistry, 18: 285296.

Bravo, J.P., Hernández, A.J., Morales, G.A., Dantagnan, P. \& Márquez, L. 2018. Digestive coordination of the gastric function in Atlantic salmon Salmo salar juveniles. Latin American Journal of Aquatic Research, 46(5): 1083-1090.

Bucking, C. \& Wood, C.M. 2009. The effect of postprandial changes in $\mathrm{pH}$ along the gastrointestinal tract on the distribution of ions between the solid and fluid phases of chyme in rainbow trout. Aquaculture Nutrition, 15: 282-296.

Campoverde, C., Rodríguez, C., Pérez, J., Gidvert, E. \& Estévez, A. 2017. Early weaning in meagre Argyrosomus regius: effects on growth, survival, digestion, and skeletal deformities. Aquaculture Research, 48: 5289-5299.

Castillo, S., Rosales, M., Pohlenz, C. \& Gatlin, D.M. 2014. Effects of organic acids on growth performance and digestive enzyme activities of juvenile red drum Sciaenops ocellatus. Aquaculture, 433: 6-12.

Castillo-Yáñez, F., Pacheco-Aguilar, R., García-Carreño, J.L. \& Navarrete-del Toro, M.A. 2004. Characterization of acidic proteolytic enzymes from Monterey sardine (Sardinops sagax caerulea) viscera. Food Chemistry, 85: 343-350.

Chiu, S.T. \& Pan, B.S. 2002. Digestive protease activities of juvenile and adult eel (Anguilla japonica) fed with floating feed. Aquaculture, 205: 151-156.

Chong, A.S.C., Hashim, R., Chow-Yang, L. \& Ali, A.B. 2002. Partial characterization and activities of proteases from the digestive tract of discus fish Symphysodon aequifasciata. Aquaculture, 203: 321333.

Gabrielczyk, J., Kluitmann, J., Dammeyer, T. \& Jördening, H.J. 2017. Effects of ionic strength on inclusion body refolding at high concentration. Protein Expression and Purification, 130: 100-106.

Grabner, M. \& Hofer, R. 1989. Stomach digestion and its effect upon protein hydrolysis in the intestine of rainbow trout (Salmo gairdneri Richardson). Comparative Biochemistry and Physiology A, 92: 8183.

Lakemond, C.C.M., de Jong, H.H.J., Hessing, M., Gruppen, H. \& Voragen, A.G.J. 2000. Soy glycinin: influence of $\mathrm{pH}$ and ionic strength on solubility and molecular structure at ambient temperatures. Journal of Agricultural and Food Chemistry, 48: 1985-1990.

Márquez, L., Robles, R., Morales, G.A. \& Moyano, F.J. 2012. Gut $\mathrm{pH}$ as a limiting factor for the digestive proteolysis in cultured juveniles of the gilthead sea bream (Sparus aurata). Fish Physiology and Biochemistry, 38: 859-869.

Munilla-Morán, R. \& Saborido-Rey, F. 1996a. Digestive enzymes in marine species. I. Proteinase activities in the gut from redfish (Sebastes mentella), seabream (Sparus aurata) and turbot (Scophthalmus maximus). Comparative Biochemistry and Physiology B, 113: 395-402.

Munilla-Morán, R. \& Saborido-Rey, F. 1996b. Digestive enzymes in marine species. II. Amylase activities in the gut from seabream (Sparus aurata), turbot (Scophthalmus maximus) and redfish (Sebastes mentella). Comparative Biochemistry and Physiology B, 113: 827-834.

Papaneophytou, C.P., Grigoroudis, A.I., McInnes, C. \& Kontopidis, G. 2014. Quantification of the effects of ionic strength, viscosity, and hydrophobicity on protein-ligand binding affinity. ACS Medicinal Chemistry Letters, 5: 931-936.

Peña, E., Hernández, C., Álvarez, C.A., Ibarra-Castro, L., Puello-Cruz, A. \& Hardy, R.W. 2015. Comparative characterization of protease activity in cultured spotted rose snapper juveniles (Lutjanus guttatus). Latin American Journal of Aquatic Research, 43(4): 641650.

Rønnestad, I., Yúfera, M., Ueberschär, B., Ribeiro, L., Øynstein, S. \& Boglione, C. 2013. Feeding behavior and digestive physiology in larval fish: current knowledge, and gaps and bottlenecks in research. Reviews in Aquaculture, 5(1): 59-98.

Servicio Nacional de Pesca y Acuicultura (SERNAPESCA). 2019. (Gobierno de Chile). Informes y Datos. Acuitultura. Cosechas Centros de Cultivo Mes. [http://www.sernapesca.cl/informes/-estadisticas]. Reviewed: July 6, 2019.

Sotoudeh, E., Shahhosseini, G. \& Aramli, M.S. 2016. Effect of gamma-irradiated and fermented soybean meal on the growth performance, body composition, and digestive enzyme activity of Caspian brown trout, 
Salmo trutta caspius, juvenile. Journal of the World Aquaculture Society, 47: 830-842.

Tonheim, S.K., Espe, M., Hamre, K. \& Rønnestad, I. 2005. Pre-hydrolysis improves utilization of dietary protein in the larval teleost Atlantic halibut (Hippoglossus hippoglossus L.). Journal of Experimental Marine Biology and Ecology, 321: 19-34.

Received: 5 December 2018; Accepted: 21 August 2019
Tonheim, S.K., Nordgreen, A., Høgøy, I., Hmare, K. \& Rønnestad, I. 2007. In vitro digestibility of watersoluble and water-insoluble protein fractions of some common fish larval feeds and feed ingredients. Aquaculture, 262: 426-435.

Xiong, D.M., Xie, C.X., Zhang, H.J. \& Liu, H.P. 2011. Digestive enzymes along the digestive tract of a carnivorous fish Glyptosternum maculatum (Sisoridae, Siluriformes). Journal of Animal Physiology and Animal Nutrition, 95: 56-64. 